\title{
TOWARD A NEW UNDERSTANDING OF SYNTRICHIA SUBMONTANA (POTTIACEAE, BRYOPHYTA)
}

\section{HOBOЕ ПОНИМАНИЕ SYNTRICHIA SUBMONTANA (POTTIACEAE, BRYOPHYTA)}

\author{
Olga M. Afonina ${ }^{1}$, Elena A. IGNATOVA ${ }^{2}$, Vladimir E. FEDOSOV ${ }^{2} \&$ OKSANA I. KuZNETSOVA $^{3}$ \\ ОЛЬГА М. АФОНИНА ${ }^{1}$, ЕЛЕНА А. ИГНАТОВА ${ }^{2}$, ВЛАДИМИР Э. ФЕДОСОВ ${ }^{2}$, ОКСАНА И. КУЗНЕЦОВА ${ }^{3}$
}

Abstract

\begin{abstract}
Syntrichia submontana (Broth.) Ochyra has been previously reported from Tajikistan, Kyrgyzstan and Mongolia. It was considered to be dioicous, with sporophytes unknown. Our study of extensive herbarium collections from Mongolia, southern Siberia and the Caucasus, as well as some collections from China revealed that this species has a much wider distribution in Asia. Its sexual condition is polyoicous: autoicous plants are most frequent, with antheridia and paraphyses lacking perigonial leaves, forming a group just below the perichaetium, but occasionally also male, female and, more rarely, synoicous plants are found in the same tuft. Mature sporophytes are rare in Mongolian collections, but they are frequent in China, southern Siberia and the Caucasus. Peristomial basal membrane is very low, consisting of $1-2(-3)$ cell rows. S. submontana is similar in gametophytic characters to $S$. sinensis (Müll. Hal.) Ochyra, and their close relationship was confirmed by molecular study (nrITS2). A description of S. submontana is amended and supplemented by sporophyte characteristics. Syntrichia longimucronata (X.J. Li) R.H. Zander is synonymized with $S$. submontana. Descriptions, illustrations, distribution and ecological data are provided for $S$. submontana and $S$. sinensis. Our molecular data also found two distinct entities within the morphologically variable $S$. laevipila Brid., which tentatively confirms recognizing of $S$. pagorum Milde as a separate species. Specimens of $S$. caninervis var. astrakhanica Ignatov, Ignatova \& Suragina from distant localities are also resolved in a clade separated from $S$. caninervis var. caninervis; thus the variety likely deserves being raised to the species level.
\end{abstract}

Резюме

Syntrichia submontana (Broth.) Ochyra была до настоящего времени известна из Таджикистана, Кыргызстана и Монголии. Вид считался двудомным, его спорофиты не были описаны. Изучение многочисленных гербарных образцов из Монголии, южной Сибири и с Кавказа, а также некоторых коллекций из Китая показало, что вид имеет гораздо более широкое распространение в Азии. Он является многодомным, при этом чаще всего представлены однодомные растения, у которых перигонии не почковидные, группа антеридиев и парафиз без покровных листочков располагается немного ниже перихеция, но иногда в той же самой дерновинке встречаются также женские, мужские и, реже, обоеполые растения. Зрелые спорофиты редки в коллекциях из Монголии, но обычны в образцах из Китая, южной Сибири и с Кавказа. Перистом характеризуется низкой базальной мембраной, состоящей из 1-2(-3) рядов клеток. По признакам гаметофита S. submontana сходна с S. sinensis (Müll. Hal.) Ochyra, и их близкое родство подтверждается также молекулярными данными (nrITS1-2). Описание S. submontana исправлено и дополнено характеристикой спорофитов. Syntrichia longimucromata (X.J. Li) R.H. Zander синонимизирована с S. submontana. Для S. submontana and S. sinensis приводятся описания, иллюстрации, обсуждается экология и распространение. Наши молекулярные данные также показывают, что внутри морфологически вариабельной S. laevipila Brid. есть две четких группы, что предположительно свидетельствует в пользу выделения $S$. pagorum Milde в качестве самостоятельного вида. Образцы S. caninervis var. astrakhanica Ignatov, Ignatova \& Suragina из отдаленных местонахождений образовали кладу, отдельную от S. caninervis var. caninervis; таким образом эта разновидность, вероятно, заслуживает видового статуса.

KEYWORDS: mosses, Pottiaceae, Syntrichia, taxonomy, new synonyms, new records, Russia, Mongolia, China, ITS.

1 - V.L. Komarov Botanical Institute Rus. Acad. Sci., Prof. Popov Str., 2, St. Petersburg, 197376 Russia - Россия 197376, г. Санкт-Петербург, ул. проф. Попова, д. 2, Ботанический институт им. В.Л. Комарова РАН; e-mail: stereodon@yandex.ru

2 - Moscow State University, Biological Faculty, Geobotany Dept., Moscow 119234 Russia - Россия 119234, Москва, Московский университет, Биологический факультет, каф. геоботаники; e-mails: arctoa@list.ru; fedosov_v@mail.ru.

3 - Tsitsin Main Botanical Garden, Russian Academy of Sciences, Botanicheskaya 4, Moscow $12 \overline{7} 276$ Russia - Pоссия 127276 Москва, Ботаническая, 4, Главный ботанический сад РAH. e-mail: oikuznets@gmail.com. 


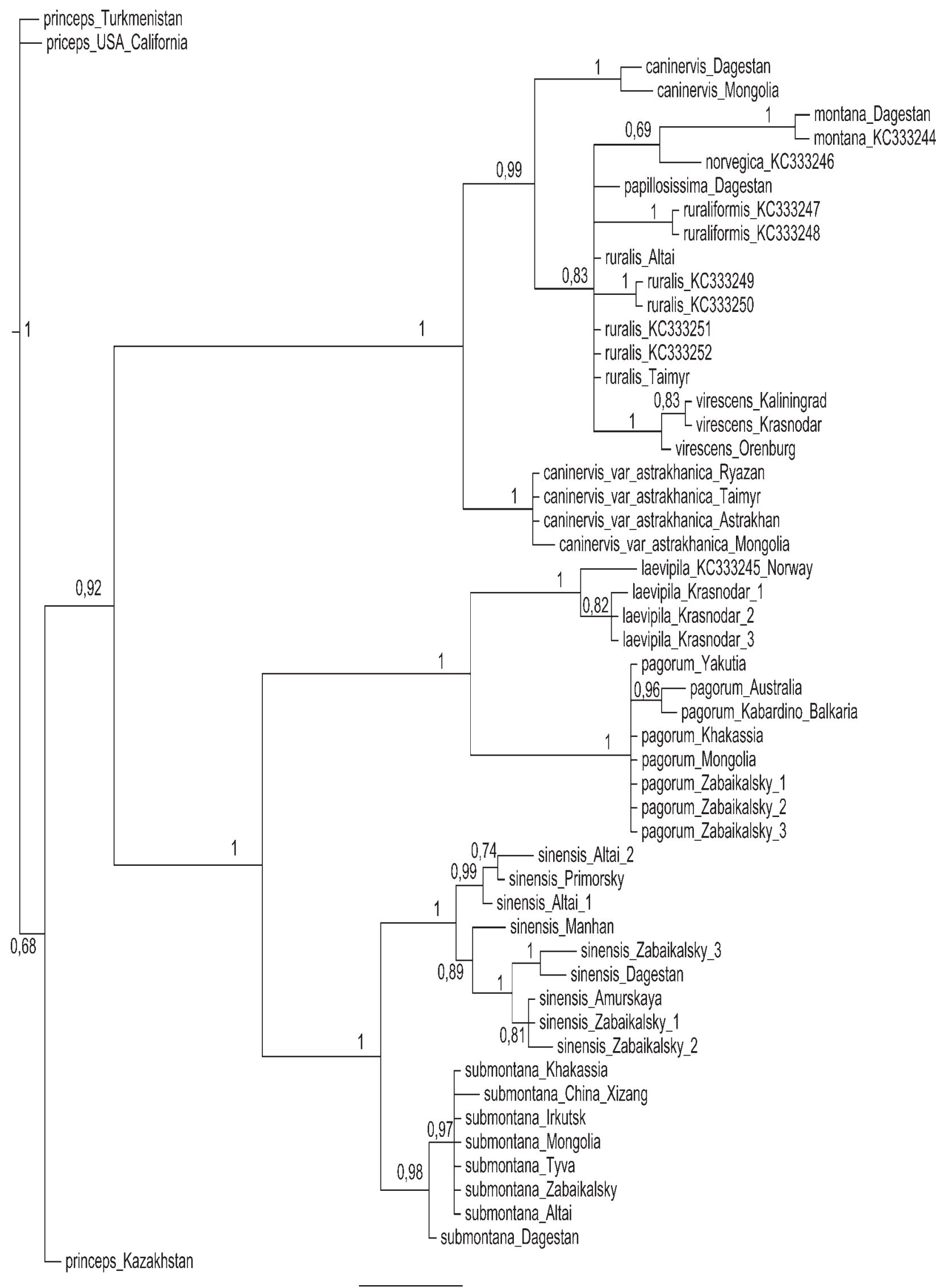

Fig. 1. Bayesian tree of Syntrichia based on 5.8RNA andITS2 sequence data. Posterior probabilites are shown at branches. 


\section{INTRODUCTION}

The genus Syntrichia Brid. is known as a difficult one for species identification, and there have been controversial taxonomic approaches to some species and their groups. The genus has been a subject of a thorough taxonomic treatment of Kramer (1980) for Palearctic, Gallego (2005) for Mediterranean region and Macaronesia, and Mishler (2007) for North America. The group of species around $S$. laevipila has been additionally revised by Gallego et al. (2004, 2005) for Europe.

In the territory of Russia, 10 species and 2 intraspecific taxa of Syntrichia were listed (Ignatov, Afonina, Ignatova et al., 2006). However, some unresolved problems with specimen identification were revealed during moss flora exploration in the southern Siberia and the Caucasus. In particular, a number of specimens similar to $S$. sinensis (Müll. Hal.) Ochyra have been found to have leaves with an unusually long hair point, basal membrane of peristome lower than in this species, and naked perigonia (which are usually bud-like). For clarifying a relationship of these specimens and $S$. sinensis we undertook a combined molecular and morphological study of this group, involving also $S$. laevipila and S. pagorum Milde, as the 'atypical $S$. sinensis' also could be interpreted as very large forms of these species in case if sporophytes are lacking.

\section{MATERIAL AND METHODS}

Morphological studies were based on collections from LE, MHA, MW and PE.

For molecular study 9 specimens of "typical S. sinensis" and 8 specimens of "atypical $S$. sinensis" were selected, representing geographically distant localities of both. In addition, 11 specimens of S. laevipila s.1. (i.e., including $S$. pagorum) from different areas of Asiatic Russia and the Caucasus were studied, 3 specimens of $S$. princeps (De Not.) Mitt., and a number of other more distantly related species of the genus. GenBank data were borrowed for nine Syntrichia specimens, mostly of $S$. ruralis and closely related species. Totally 53 sequences were included in the analysis.

Only ITS2 is included in the study by three reasons: (1) ITS1 was unavailable in GenBank for these species; (2) ITS1 sequences of species even within one genus cannot be unequivocally aligned; and (3) ITS2 has numerous substitutions, clearly correlating in most cases with the species as they are currently known based on morphology. Specimen vouchers and GenBank accessions are in Appendix 1.

Laboratory protocol was essentially the same as in previous moss studies, described in detail by, e.g., Gardiner et al. (2005). ITS sequences were aligned independently using MUSCLE (Edgar, 2004), and modified manually using BioEdit 7.0.9.0 (Hall, 1999).

For the rooting of trees Syntrichia princeps was chosen, because it was difficult to align ITS sequences of Syntrichia with any ITS sequences of related genera, e.g.,
Tortula Hedw., and sequences of $S$. princeps visually were the most distinct from other major groups of sequences. Supplementary analyses with the rooting on $S$. norvegi$c a$ both by Bayesian methods and maximum parsimony in TNT (not shown) found $S$. princeps to be distant from $S$. sinensis-S. laevipila s.1.-complex, which is in the main focus of the present study.

Bayesian analyses were performed using MrBayes (Huelsenbeck et al. 2001), version 3.2.0, running in two parallel analyses, consisting each of six Markov chains of 10,000,000 generations with a sampling frequency of one tree each ten thousand generations and the chain temperature at 0.05 . Parameters of the substitution model were estimated during the analysis (six substitution categories, a gamma-distributed rate variation across sites approximated in four discrete categories and a proportion of invariable sites). Convergence of the analyses was evaluated using Tracer 1.4.1 (Rambaut \& Drummond 2007 ) to check that ESS values were all greater than 200 (default burning). The consensus tree was then combined after first $25 \%$ of trees were discarded as a burn-in. All analyses were performed on the Cipress Science Gateway (http://www. phylo.org/portal2).

\section{RESULTS}

Phylogenetic analysis resulted in a Bayesian tree (Fig. 1) consisting of two well-supported clades, one including species of $S$. ruralis-S. caninervis-S. virescens-complex, and another composed of $S$. sinensis-S. laevipila s.l.-complex.

The species of the former clade will be the subject of a separate analysis. Here we just point out that this preliminary analysis of the group supports the elevation of $S$. caninervis var. astrakhanica to the species level.

Syntrichia sinensis-S. laevipila s.1-clade consists of two maximally supported subclades. The first of them represents typical $S$. sinensis and a species in question, each forming a clade. Nine specimens of $S$. sinensis from geographically distant localities (from Primorsky Territory in Russian Far East, Inner Mongolia in China and westward to Dagestan in the Caucasus) form the clade with the posterior probability 1.00 ; another clade with the support 0.98 consists of six specimens of "atypical $S$. sinensis" from southern Siberia, one form Dagestan in the eastern part of Caucasus, one specimen of $S$. submontana from Mongolia and one specimen from Tibet, collected not far from the type locality of $S$. longimucronata (cf. Fig. 3). Being largely sympatric with $S$. sinensis, this taxon has also small, but fairly stable morphological distinction from it.

A second subclade is formed by specimens of $S$. laevipila s.1. The present Bayesian analysis subdivides them in two clades, both with support $\mathrm{P}=1.00$. One of them includes dioicous plants, referred here to $S$. pagorum, while another comprises autoicous plants, corresponding to $S$. laevipila $\mathrm{s}$. str. in its common circumscription. Within polytomy of six Siberian and Mongolian plants 
of $S$. pagorum, a moderately supported $(\mathrm{PP}=0.96)$ nested clade occurs, composed by Central Caucasian and Australian plants. The S. laevipila s.str. subclade includes one Norwegian specimen clearly differentiated from three Caucasian specimens (though all three from a relatively restricted area).

\section{DISCUSSION}

As soon as it became clear that the plants of unknown Syntricha in question cannot be just a marginal phenotype of $S$. sinensis, an expanded search for appropriate name has been undertaken yielding a possible attribution of the former to S. longimucronata (X.J. Li) R.H. Zander. This species was described from Xizang Province of China (Li, 1981), and our plants in question were in agreement with its description in most gametophytic and sporophytic characters (i.e., presence of central strand in stem and hydroids in costa, highly recurved leaf margins, long and weakly denticulate hair-point, low basal membrane of peristome, as well as autoicous sexual condition, though perigonia were not described in details). The only character which we did not observe in our plants was leaf marginal border "consisting of several rows of thick-walled, or sometimes elongated cells, yellowish or brownish" (Li et al., 2001). Nevertheless, the illustration on p. 219 (Plate 132: 2) shows an unbordered leaf margin. This character is known to be variable in other species of Syntrichia, i.e., S. laevipila, representing both clearly bordered and totally unbordered leaves in different specimens. In all collections from China available for our study, including a locality from Xizang Province, leaves were not bordered.

Another species name, which could be attributed to our plants was S. submontana (Broth.) Ochyra. This species was described from Issyk Kul Lake vicinity in Kyrgyzstan (Brotherus, 1931). The description indicates a dioicous sexual condition and absence of sporophytes in the type specimen. Later, S. submontana was reported also from several localities in Pamir Mts of Tajikistan (Mamatkulov, 1990). Sporophytes were not found as well in this area. This fact did not allow us to use this name for the plants, which were autoicous in most of our collections, and often bearing capsules. However, there was much in common in gametophytic structure between our plants and the description and illustrations of S. submontana (Brotherus, 1931; Savicz-Lyubitzkaya \& Smirnova, 1970; Mamatkulov, 1990; Kramer, 1980). Among diagnostic characters of this species, erecto-patent spatulate leaves with rounded apices and narrowly recurved margins, long and weakly denticulate hyaline hair-point, weakly scabrous dorsal side of costa, presence of stem central strand and costal hydroids were listed.

In 1970, S. mongolica Boros was described from Mongolia. Shortly afterwards it was synonymized with S. submontana by Kramer (1980), despite the former species being described as autoicous. This synonymization was accepted by Abramov \& Abramova (1983) and
Tsegmed (2001, 2010). Tsegmed (2010) in "Moss flora of Mongolia" describes S. submontana as a dioicous species with sporophytes unknown and with rather wide distribution in the country. We have studied a syntype of $S$. mongolica in LE and numerous Mongolian collections in MHA made by M.S. Ignatov during an expedition to Gobi-Altai area in 2001 and identified as S. submontana. These specimens were very similar to an "unknown species" from southern Siberia and the Caucasus in gametophytic characters, although the plants from Gobi were smaller and looked damaged with respect to unfavorable growth conditions in the dry area. According to Ignatov et al. (2004) this plant is one of the most common in the xeric environments and also commonly produces sporophytes, which naturally not always successfully come to maturity, thus often seen as immature ones. Our study of gametangia distribution revealed a wide variation in plant sexual condition. The most common result of study of a large specimen is that the female, male and autoicous plants occur in the same tuft; more rarely synoicous and sterile plants were found.

Very characteristic are the naked antheridia in S. submontana, sitting on stem among paraphyses, without perigonial leaves, contrary to bud-like perigonia of $S$. sinensis and many other species. The latter case, i.e., when bud-like perigonia are developed on a separate very short branch, has been reported by Zander (1993) as the only possible in the description of Syntrichia. Thus, S. submontana is obviously an exceptional case in the genus.

Numerous collections from Mongolia helped us to understand why S. submontana was described as dioicous. Its sexual condition is variable, thus small collection from extreme environments may often have only one sex expressed, if any. The ITS sequence data of the polyoicous Mongolian specimen was identical with mainly autoicous plants from south Siberia and Caucasus.

The holotype of Syntrichia (Tortula) submontana has naked perigonia, grouped with paraphyses laterally near shoot apex and subapical innovations. This fact confirms the applicability of this name for plants under question. No female plants were seen in the holotype, although we hesitated to investigate every shoot due to paucity of material in the specimen. However, considering the variation of sex expression in bigger collections of the species, the absence of females both agrees with the original diagnosis and does not contradict the amended circumscription of the present study.

Curiously, Syntrichia sinensis has also been described originally as dioicous, likely due to the fact that perigonia are not always found in specimens of this species. They are rather inconspicuous being quite similar to young sterile innovations, albeit found in all sufficiently large collections we studied. The holotype of this species is the collection made in June 1894 by Giraldi from Schaanxi ('Schen-si'), In-kia-puo ('Iu-kia-po' in protologue is an obvious misprinting, as it is clear from nu- 
merous labels in H, S, FI for other species, and also Chen' text). It has beed studied by Chen (1941) but then likely destroyed in Berlin during the 2d World War. Neither holotype, nor isotypes were located by Kramer (1980) and Gallego (2005), who at the same time did not substitute it by neotype. However, as the distinction between $S$. submontana and $S$. sinensis involves a character not described in the original description, thus neotypification of $S$. sinensis is proposed.

Müller (1896) originally described Barbula (Syntrichia) sinensis from one collection, but later, in the second part of the "Bryologia provinciae Schen-si Sinesis" (Müller, 1897, page 254) again labeled Barbula (Syntrichia) sinensis as 'nova species', and cited two more specimens. The second of them, from Lun-san-huo is annotated as a specific form, although without any formal recognition 'forma foliis teniuter pungentibus', thus the first specimen, from Lao-y-san, collected by Giraldi in March 1896 is the reasonable candidate for the neotype. Fortunately this specimen is present in H-BR. Being in full agreement with the protologue, it is proposed here as the neotype of $S$. sinensis. The plants of the neotype have antheridia surrounded by perichaetial leaves, i.e., having the structure common for the genus Syntrichia, except for S. submontana. At the same time, this neotype has leaves with a relatively long hair point, which somewhat disagrees with the most common current understanding of this species as one with a short hyaline awn (Savicz-Lyubitskaya \& Smirnova, 1970; Kramer, 1980; Gallego, 2005; Mishler, 2007), although Li (2001) described the hair point as 'rather long'.

This problem is complicated also due to the fact, that in addition to 'Barbula (Syntrichia) sinensis' Müller (1898) described also two other species, Barbula (Syntrichiae albipilae) brachypila Müll. Hal. and Barbula (Syntrichiae rubripilae) erythrotricha Müll. Hal. from about the same area. Later, P.-C. Chen (1941) in his monograph of East-Asiatic Pottiaceae reduced both of them into synonymy of Syntrichia alpina Jur., a European species, which however appeared to be illegitimate, and corresponds to the current understanding of S. sinensis. However, in a view of the segregation of Syntrichia submontana both taxa were checked, especially Barbula erythrotricha, as it has been described as having long hyaline hair-point, the character more characteristic to S. submontana than to at least the most common phenotypes of S. sinensis in Russia and Europe. Nevertheless, the perigonial structure of the plants, selected as lectotype by Chen (1941), it is not different from the neotype of $S$. sinensis, thus the earlier synonymization is simply confirmed here.

The studied syntype of Barbula brachypila has the same perigonial structure, and we are currently inclined to confirm this synonymization too, although the discussion below explains less definite situation in case of this name.
We found that specimens of $S$. sinensis from Russia show variation in hair-point length. Most specimens match the description of Gallego (2005), who estimates its length at $0.1-0.5 \mathrm{~mm}$. At the same time, several specimens possessed leaves with longer hair-points, up to 0.9 $\mathrm{mm}$ long in upper leaves. Furthermore, three such specimens, one from Primorsky Territory and two from Altai, formed a separate subclade within $S$. sinensis-clade in the nrITS Bayesian tree (Fig. 1, see also Fig. 4: 1113). According to the description (Müller, 1998), B. brachypila is characterized by costa excurrent in a short awn, whereas awns of $B$. sinensis and $B$. erythrotricha are described as "foliorum pilo plus minus longo tenui denticulato". We have studied 3 specimens of $B$. sinensis and 3 specimens of $B$. erythrotricha from H-BR identified by Carl Müller, as well as a specimen of B. brachypila cited in protologue from LE. All these specimens of $B$. erythrotricha and $B$. sinensis, as well as other specimens from Schen-si identified by V.F. Brotherus (H-BR) possess awns 0.6-0.8 $\mathrm{mm}$ long, while they are shorter, up to $0.4 \mathrm{~mm}$, in the specimen of $S$. brachypila (see Fig. 5). In other essential characters, i.e., peristome basal membrane height (36 cells high) and autoicous sexual condition with bud-like perigonia, all studied specimens are uniform and fit well the concept of $S$. sinensis accepted by most authors.

The molecular data suggest a slight differentiation between long- and short-awned phenotypes, but this problem cannot be solved with the present sampling and limited study of Chinese material. Therefore we are accepting $S$. sinensis in a broad sense at the moment, in agreement with Chen (1941), Kramer (1980), Gallego (2005), Li et al. (2001), pending the solution in a specifically addressed study.

Although not specifically addressed to other groups of Syntrichia, the present analysis highlights a need of additional study of $S$. laevipila-complex. Recent publications of Gallego et al. (2004, 2005) demonstrated a continuous variation of morphological and molecular characters within S. laevipila s.1., including S. pagorum, which was recogniozed by, e.g., Crum \& Anderson (1981) and Stone (1971). Our molecular phylogenetic analysis however found two maximally supported clades that are hundred-percent congruent with the sexual condition, a character often used as a main one for differentiation of S. laevipila and S. pagorum. The present limited sampling precludes a convincing conclusion, but calls attention to further studies.

Tree topology suggests also a need of more narrow species distinction in $S$. caninervis-group, as $S$. caninervis var. astrakhanica, a taxon described only recently (Ignatov et al, 2002), constitutes another lineage, not closely related to var. caninervis (Fig. 1). It seems that the former is no less widespread in Russia than the latter. The re-evaluation of the type of $S$. caninervis, described from Tibet in China, will be essential, as both taxa occur in nearby Mongolia. 

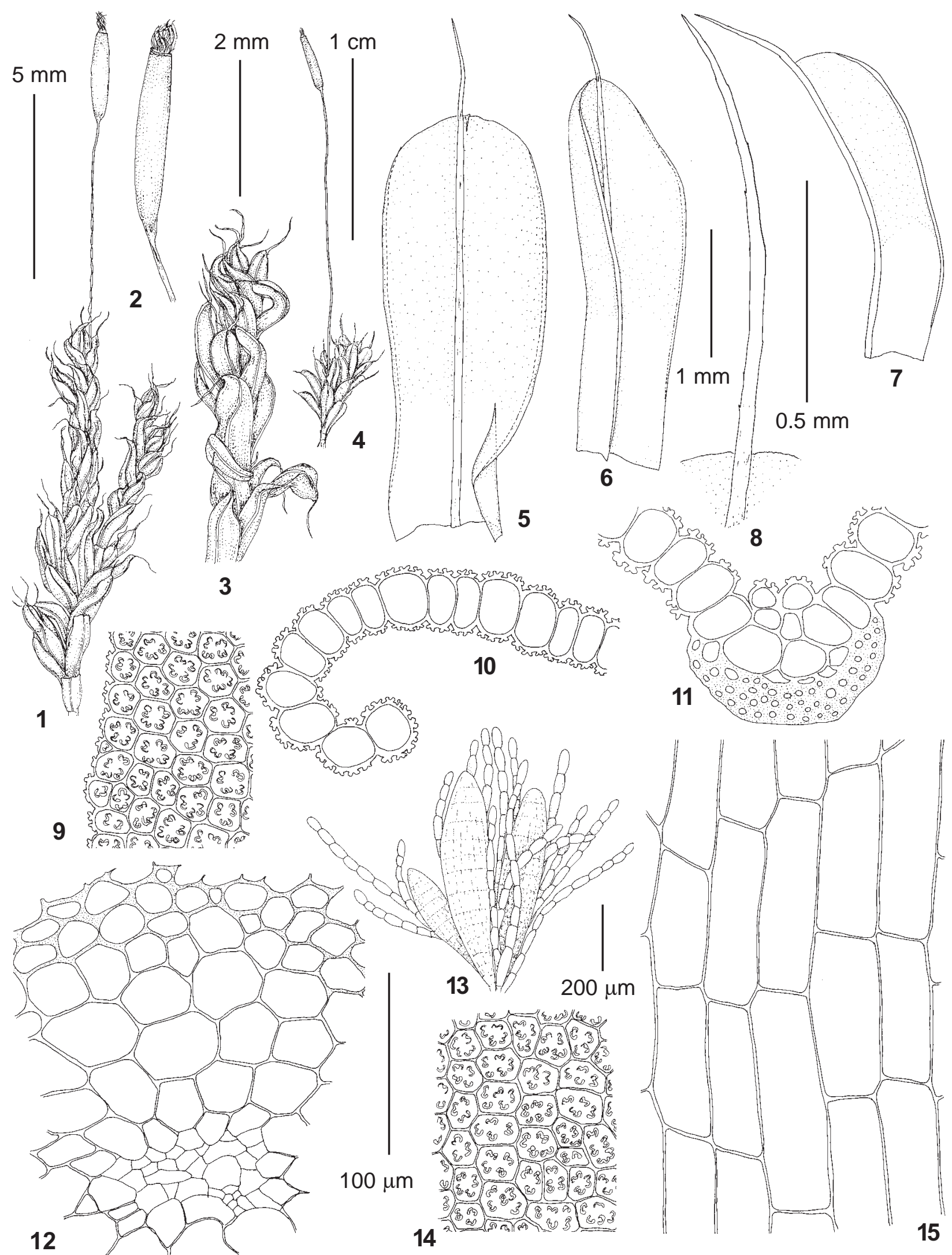

10

11

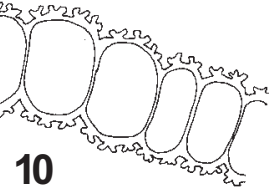

$00000000.0 \%$
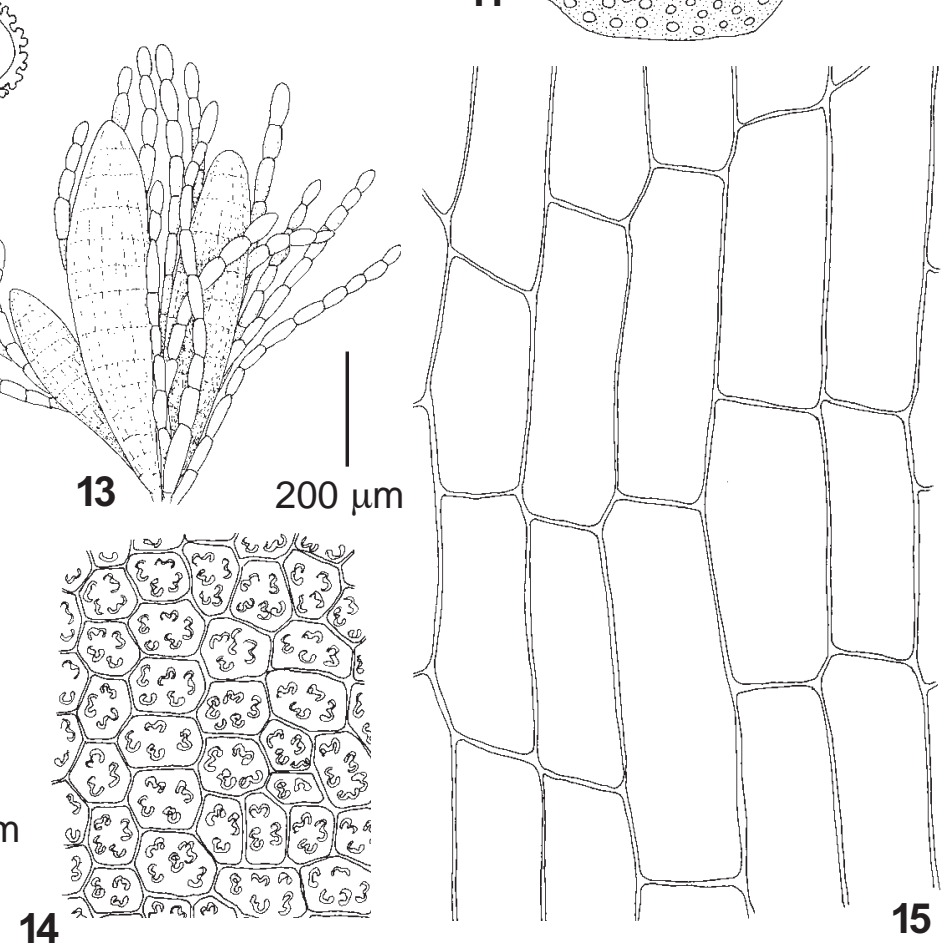

Fig. 2. Syntrichia submontana (Broth.) Ochyra (from: Russia, Zabaikalsky Territory, Sokhondinsky Biosphere Reserve, Agutsa River, Afonina A3510, LE): 1, 3 - habit, dry; 2 - capsule; 4 - habit, wet; 5, 7 - leaves; 6 - perichaetial leaf; 8 - leaf hair-point; 9 - cells at leaf margin in distal part; 10 - leaf transverse section at margin; 11 - transverse section of costa; 12 - stem transverse section; 13 - antheridia and paraphyses without perigonial leaves; 14 - median laminal cells; 15 - basal laminal cells. Scale bars: $1 \mathrm{~cm}$ for $4 ; 5 \mathrm{~mm}$ for $1 ; 2 \mathrm{~mm}$ for 2,$3 ; 1 \mathrm{~mm}$ for $5-7 ; 0.5 \mathrm{~mm}$ for $8 ; 200 \mu \mathrm{m}$ for $13 ; 100 \mu \mathrm{m}$ for 9-12, 14-15. 


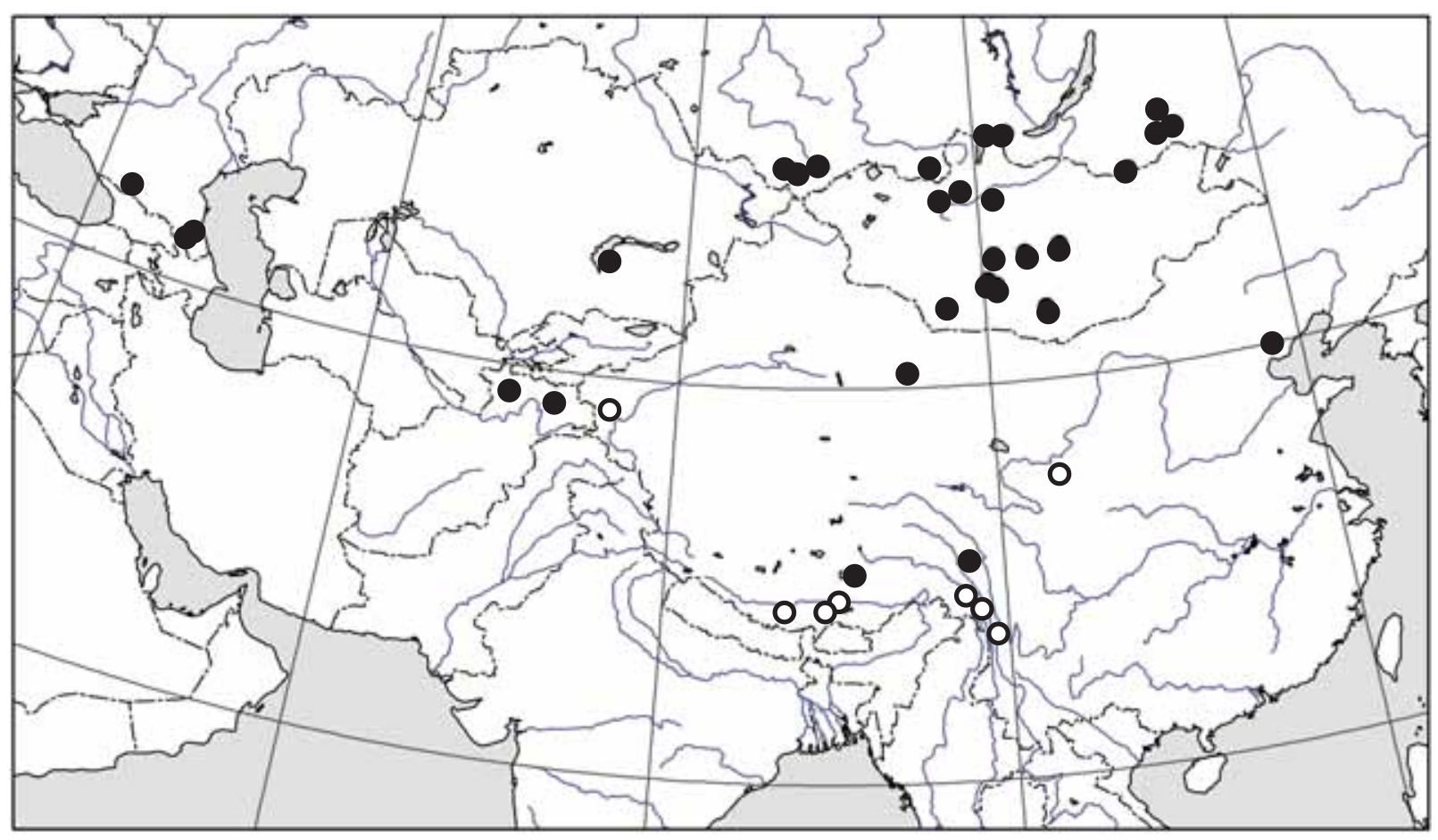

Fig. 3. Distribution of Syntrichia submontana (Broth.) Ochyra, based on specimens studied (solid circles) and literature data for S. longimucronata from Li et al. 2001 (open circles).

\section{TAXONOMIC TREATMENT}

Syntrichia submontana (Broth.) Ochyra, Fragm. Florist. Geobot. 37: 213. 1992. - Tortula submontana Broth., Trudy Bot. Sada Akad. Nauk S.S.S.R. 42(2): 168. 1931. Holotype: Turkestan. Ur-Tokai - Kutemaldy. 1896 7/6 leg. V.F. Brotherus (H 3148373).

Syntrichia mongolica Boros, Trans. Brit. Bryol. Soc. 6: 70. f. 1-2. 1970. Type: Mongolia or. In rupestribus silicat. prope Baronurt. Alt. ca. 1000 m. 23.VIII.1967. R. Moldvai (isotype in LE!). Synonymized by Kramer (1980).

?Syntrichia longimucronata (X.J. Li) R.H. Zander, Bull. Buffalo Soc. Nat. Sci. 32: 269. 1993. - Tortula longimucronata X.J. Li, Acta Bot. Yunnan. 3: 107. f. 4. 1981. Type: 'China, Xizang, Jia-li Co., D.-D. Tao 5313a' (holotype in HKAS, not seen).

Figs. 2-3, 5: 2-3, 8

Plants medium-sized, in rather loose turfs, dull green, yellowish- or brownish-green in upper part, reddish brown below. Stem 0.5-2.0 mm, erect, simple or irregularly branched, loosely tomentose throughout, with weak central strand, thickened cortical cells in 2-3 layers and weakly differentiated hyalodermis. Leaves contorted or twisted when dry, spreading to weakly recurved when moist, oblong-elliptic to oblong-lingulate, 2.0-3.5×0.6$1.2 \mathrm{~mm}$, not constricted at midleaf, weakly keeled in upper part, sometimes with longitudinal folds, rounded at apex; margins recurved from above leaf base to near apex, unbordered, smooth or crenulate distally due to bulging cells; costa strong, 65-90 $\mu \mathrm{m}$ wide at base, weakly tapering distally, reddish-brown, smooth on dorsal side, excurrent in an awn 0.5-1.5 mm long, weakly and distant- ly denticulate, reddish-brown at base and hyaline at most of its length or, occasionally, yellowish or brownish at most length except small apical portion; costa in transverse section with one layer of guide cells, two layers of smaller adaxial cells, ventral surface papillose, abaxial stereid band of 3(-4) layers, with hydroids; leaf lamina unistratose; upper and median laminal cells roundedquadrate or hexagonal, thin-walled, 12.5-20×(10-)12-20 $\mu \mathrm{m}$, papillose, with 3-6 papillae per cell, papillae bifurcate, not pedicellate, $2.5 \mu \mathrm{m}$ high; basal laminal cells forming a clearly differentiated hyaline area, rectangular, smooth, thin-walled, sometimes weakly collenchymatous, basal juxtacostal cells $50-115 \times 17.5-35 \mu \mathrm{m}$, basal marginal cells shorter and narrower. Polyoicous: male, female, autoicous and, more rarely, synoicous plants are occasionally found in same or different collections. Perichaetial leaves similar to stem leaves, but sometimes inner perichaetial leaves smaller and narrower than stem leaves. In autoicous and male plants, antheridia and paraphyses in clusters just below perichaetium or below shoot apex, perigonial leaves lacking. Seta erect, reddish brown, $1.0-2.0 \mathrm{~cm}$ long, spirally twisted to the right distally. Urn reddish brown, 2.5-3.5×0.7-0.8 mm, cylindrical, straight or slightly curved; operculum long conical, 1.2-1.4 mm long; peristome 0.9-1.4 mm high, with basal membrane of 3-6 cell rows. Spores 12-15 $\mu \mathrm{m}$, finely papillose.

Taxonomy. By studying the isotype of Syntrichia mongolica, we confirm Kramer (1980)' conclusion on the identity of this species with $S$. submontana. Although we did not see type material of $S$. longimucronata, we presume its identity with $S$. submontana basing on: (1) 
coincidence with description and illustrations, (2) same ITS2 sequence and the presence of naked antheridia in specimen from the area near the type locality.

Variation. The most variable character of $S$. submontana is sexual condition of plants. Collections from southern Siberia and the Caucasus, as well as from China and some areas of Mongolia, are autoicous and bear mature sporophytes. However, some plants with only female gametangia are also found in the same specimens. At the same time, Mongolian samples from harsh environments are mostly polyoicous, with a mixture of female, male, autoicous and, more rarely, synoicous plants in the same specimen. According to the description of S. submontana (Brotherus, 1931; Mamatkulov, 1990), specimens from Middle Asia were only dioicous.

There is some variation in hair-point color: in most specimens from Russia and Mongolia hair-points are hyaline, with a small basal portion brownish, while in a specimen from Xizang and a few ones from Transbaikalia hair-points are brownish-colored on most of their length, with only small distal portion being hyaline.

We did not observe the leaf marginal border in any studied specimen, but, as its presence is reported for $S$. longimucronata (Li, 1981; Li et al., 2001), this character may show variation.

Differentiation. Collections from Russia which we attribute now to Syntrichia submontana were previously mostly identified as $S$. sinensis. They are similar to the latter species in size of plants, leaf shape and size, presence of stem central strand and hydroids in costa, and autoicous sexual condition. At the same time, plants with mature sporophytes could be easily recognized even under stereomicroscope: they differ in the height of basal membrane of peristome (very low, 1-2 cell rows in $S$. submontana vs. higher, 3-6 cell rows in S. sinensis, see Fig. 5: 1-2) and, in most cases, in the hair-point length (0.5-1.5 mm in S. submontana vs. 0.1-0.3 mm in S. sinensis). Leaf margins are more strongly recurved almost to the apex in $S$. submontana, whereas they are less recurved in proximal 1/2-2/3 of leaf length in S. sinensis. There is also a stable difference in structure details of male inflorescences. In S. submontana, perigonial leaves are lacking and antheridia with paraphyses form a compact group just below the perichaetium (Fig. 5: 3), more rarely at some distance below. In $S$. sinensis, perigonia are bud-like, covered by small, obtuse perigonial leaves (Fig. 5: 4), usually situated at some distance below perichaetia. If the plants of S. submontana are dioicous, male inflorescences are also naked, lateral or subterminal. The most difficult case is if sporophytes are lacking or immature, perigonia are not found and awns exceed $0.5 \mathrm{~mm}$ : such plants can be attributed both to $S$. submontana and to long-awned $S$. sinensis. In this case, leaf margin recurvation (longer in S. submontana) can be helpful, but such plants cannot be identified with certainty.

Ecology. The species grows in similar habitats to $S$. sinensis, but generally in more xeric areas. In Transbaikalia, it prefers dry cliffs and rock outcrops at slope bases, boulders and rocks in open birch forests, more rarely it grows on trunk bases of birch and elm trees and once it was found on woody roof of a shed. In Altai it was collected on dry rocks and cliff crevices, both open and forested, once it was found on soil along a road and at base of birch trunk. In Dagestan it grows exclusively on dry calcareous rocks and cliffs, contrary to $S$. sinensis wich is often found also on trees in this area. Elevations range was documented between 600-1200 $\mathrm{m}$ in Transbaikalia, 450-2100 $\mathrm{m}$ in Altai and 1700-2300 in the Caucasus.

Distribution. The distribution of Syntrichia submontana includes mountain areas of China (Xizang, Yunnan, Shaanxi, Sichuan, Gansu, Hebei and Xinjiang Provincies), Mongolia (almost throughout the country), Kyrgyzstan and Tajikistan. In Asiatic Russia, the species is common in southern part of Zabaikalsky Territory and was also found in western part of Irkutsk Province and Buryatia, in Tyva and in several localities in Altai Republic, mostly in rather xeric areas along tributaries of Chuya River and Chulyshman Rivers. It is also common at places in eastern Caucasus (Dagestan) and found once in Karachaevo-Cherkessian Republic.

Specimens examined: CHINA: Kansu occidentalis, ad fluv. Bardun-fischii, 11.V.1886, Potanin s.n. (LE); [Hebei Prov.], Weichang, X. 1899, Palibin s.n. (LE); prov. Kansu occ., ad. fl. Solomo vallis fl. Bardun, 16.V.1886, Polunin s.n. (LE); Prov. Szechuan, Mt. Omei, Ching-ding, ca $3000 \mathrm{~m}$. ad rupes regions subalpinae, subskiophila, Photophila. c.sp., VIII. 1942, Chen s.n. (LE); Xizang ( $31^{\circ} 18.5^{\prime}$ N, 9758.54'E), 3.VIII.2001, Miwa \& Y. Yia 3825 (PE). MONGOLIA: Kosogol Lake, 2.VII.1902, Elenkin s.n. (LE); Hangai, 20.VII.1972, Tsogt \& Kukk 32 (LE); Selenginsky aymag, Buteleeliyn nuruu Ridge, 25.VIII.1974, Tsegmed 2171 (LE); Ubsu-Nurski aymag, Turgen Ridge, 7.VIII.1973, Tsegmed 380 (LE); Arkhangai Aimag, Sumein-am Mt., 9.VII.1970, Tsogt s.n. (MHA); Bayankhongor Aimag, 43 km W of Bayan-Undur somon, 27.VIII.1972, Tsogt \& Kukk 393 (MHA); Bayan-Hongor Province, between Ikh-Bogd and BagaBogd Mts, Ignatov 01-652 (MHA); Khangai Mts, Egiin-Daba pass, Chulutu-gol River, 5.VIII.1973, Golubkova \& Tsogt s.n. (MHA); Khangai, $7 \mathrm{~km}$ N of Tarialei somon, 22.VII.1972, Tsogt $\&$ Kukk 32 (MHA); Bulgan Aimag, Khutag somon, Altaid River mouth, 7.VIII.1974, Tsegmed 1768 (MHA); Omnogovi Province, Gurvansaikhan National Park, Ignatov 01-658, 01-661, 01-654 (MHA); Ovorhangai Province, $10 \mathrm{~km} \mathrm{~N}$ of Arvanheir, Ongi River, Ignatov 01-651, 01-656 (MHA); Dungovi Province, Aerdaenaedalai somon, Ignatov 01-660 (MHA).

ASIATIC RUSSIA: Irkutsk Province: Tunkinsky District, Sayan Mts, Nilova pustyn', 30.V.1902, Elenkin s.n. (LE); western shore of Baikal Lake, Bolshie Koty, 11.IX.1981, Filin s.n. (MW); Slyudyanka District, Kultuk, Kosovich-Anderson B-741 (MHA). Republic of Buryatia: East Sayan Mts, upper Oka River, Dodo-Zhahna village, 2.VII.2008 (with S. sinensis), Afonina 00708 (LE); Arshan Settlement (514ㅇ'N, 102²7'E), $1100 \mathrm{~m}$ alt., 15.VIII.1993, Shevyreva \& Konovalova s.n. (MHA). Zabaikalsky Territory (selected specimens): Aksha District, Tsagan-Olui Settlement, 12.X.1909, Mikhno s.n. (LE); near Aginskoe Settlement, left bank of Aga River $\left(51^{\circ} 07^{\prime} \mathrm{N}, 114^{\circ} 40^{\prime} \mathrm{E}\right)$, 15.VII.2006, Afonina 4706 (LE); right bank of Ingoda River 5 


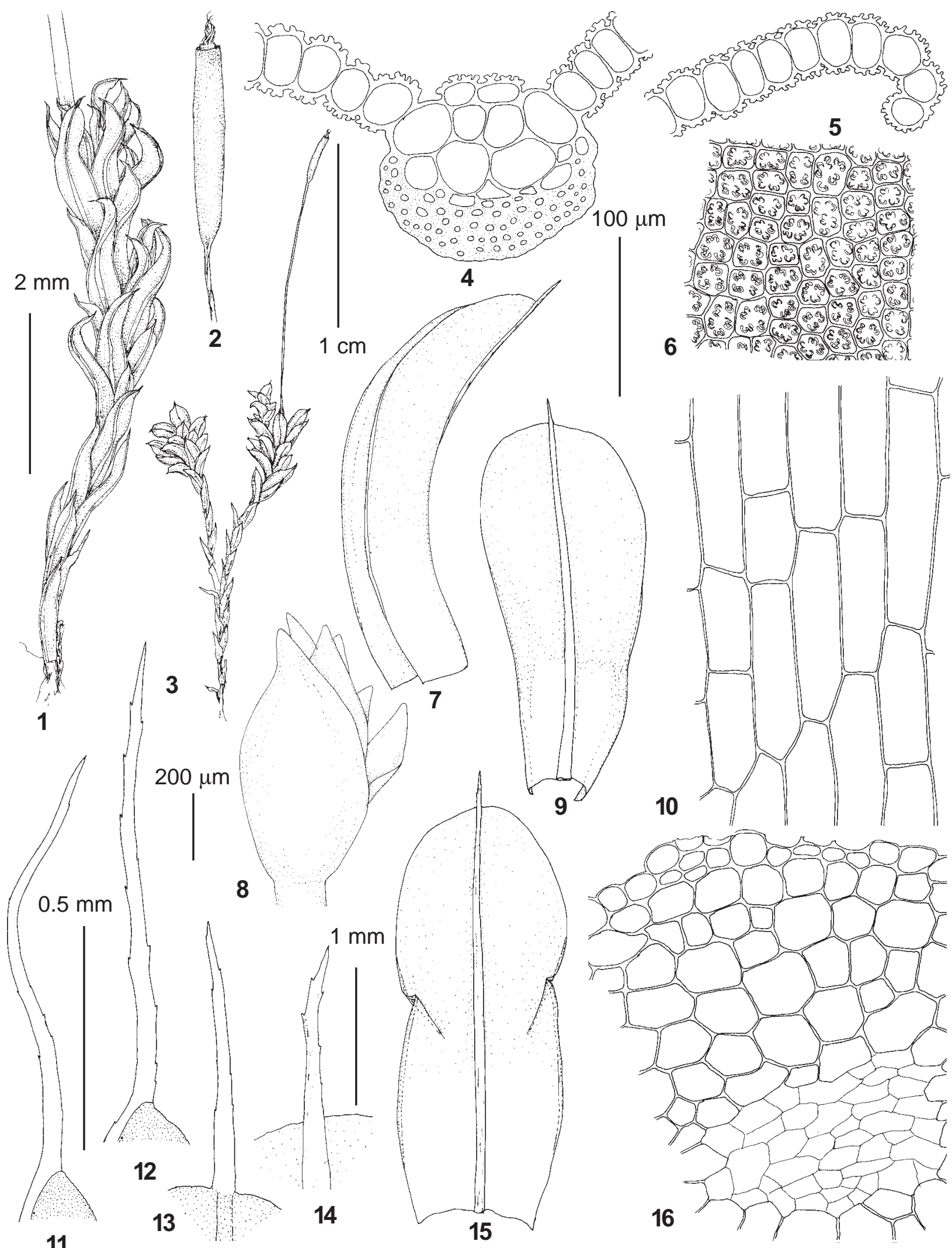

Fig. 4. Syntrichia sinensis (Müll. Hal.) Ochyra (1-10, 14-16 - from: Russia, Dagestan, Gunib, Ignatov \& Ignatova \#09-255, MW; 11 - from: Russia, Altai, Chemal, Ignatov \& Ignatova 34/109, MHA; 12 - from: Russia, Primorsky Territory, Chandolaz, Ignatov et al. 06-2825 MHA; 13 - from: Russia, Altai Republic, Teletzkoe Lake, 3.VI.1989, Ignatov s.n. (MHA). 1 - habit, dry; 2 - capsule; 3 - habit, wet; 4 - transverse section of costa; 5 - leaf transverse section at margin; 6 - median laminal cells; 7, 9, 15 - leaves; 8 - bud-like perigonium; 10 - basal laminal cells; 11-14 - leaf hair-points; 16 - stem transverse section. Scale bars: $1 \mathrm{~cm}$ for $3 ; 2 \mathrm{~mm}$ for $1-2 ; 1 \mathrm{~mm}$ for $7,9,15 ; 0.5 \mathrm{~mm}$ for $11-14 ; 200 \mu \mathrm{m}$ for $8 ; 100 \mu \mathrm{m}$ for $4-6,10,14$. 
$\mathrm{km} \mathrm{S}$ of Darasun railway station $\left(51^{\circ} 52^{\prime} \mathrm{N}, 113^{\circ} 43^{\prime} \mathrm{E}\right), 658 \mathrm{~m}$ alt., on rocks, 14.VII.2007, Afonina 05107 (LE); National Park “Alhanay" (5050’N, 113²2’E), 1048 m alt., 24.VII.2007, Afonina 08307 (LE); Sokhondinsky Reserve, Enda River (49 26'39'N, 11050'55'E), 1162 m alt., 24.VIII.2011, Afonina 5911 (LE); same place, 24.VIII.2011, Afonina 6011 (LE); Enda River, Khukhe-Baytsa Creek (49²8'17’N, 110 51'58'E), 1214 m. alt., 27.VIII.2011, Afonina 7511 (LE); Tyva Republic: Erzinsky District, Tara-Khol' Lake, 13.IX.2003, Korobkov s.n. (LE). Altai Republic: Argut canyon, 23.VII.1903, Krylov s.n. (LE); Ongudai District, Malyj Yaloman Creek (50²8'N, 86 33'E), $900 \mathrm{~m}$ alt., 31.VII.1991, Ignatov \& Ignatova 25/119 (MHA);

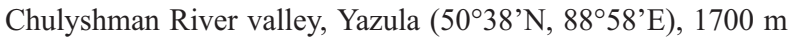
alt., 25.VI.1989, Ignatov 0/1547 (MHA); Ongudai District, Chuya

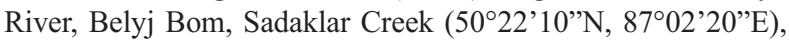
$920 \mathrm{~m}$ alt., Seregin \& Seregina M-2222 (MW); Kosh-Agach District, Severo-Chuisky Mt. Range, Chibit, Oroi Creek

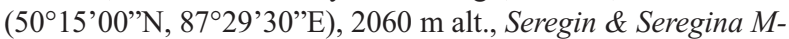
2164 (MW). CAUCASUS: Dagestan: Charoda District, Gunukh $\left(42^{\circ} 13^{\circ} \mathrm{N}, 46^{\circ} 41^{\prime} \mathrm{E}\right), 2200 \mathrm{~m}$ alt., Abakarova \& Ignatov $11-2012$ (MHA); Charoda District, Urukh-Sota (42 $\left.2^{\circ} 18^{\prime} \mathrm{N}, 46^{\circ} 46^{\prime} \mathrm{E}\right), 2300$ $\mathrm{m}$ alt., Ignatov \& Abakarova 11-7 (MHA); Gunib District, Gunib $\left(42^{\circ} 25^{\prime} \mathrm{N}, 46^{\circ} 55^{\prime} \mathrm{E}\right), 1760 \mathrm{~m}$ alt., Ignatov \& Ignatova 09-568, 09-542 (MHA). Karachaevo-Cherkessian Republic, Gudgora, $\left(43^{\circ} 43^{\prime} \mathrm{N}, 42^{\circ} 19^{\prime} \mathrm{E}\right), 2200 \mathrm{~m}$ alt., on soil in cracks of rock, 14.VII.2010, Ukrainskaya s.n. (LE).

Syntrichia sinensis (Müll. Hal.) Ochyra, Fragm. Florist. Geobot. 37: 213. 1992. - Barbula sinensis Müll. Hal., Nuovo Giorn. Bot. Ital., n. s. 3: 100. 1896. - Tortula sinensis (Müll. Hal.) Broth., Nuovo Giorn. Bot. Ital. 13: 279. 1906. Neotype: China interior, Provincia Shensi sept., in monte Lao-y-san, Mart. 1896, legit Rev. Jos. Giraldi, determ. Prof. C. Müller sub n. 1382 (H-BR 4205016).

Barbula alpina Bruch \& Schimp., Bryol. Eur. 2: 101. 1842, nom. illeg. [non Barbula alpina Steud., Nomencl. Bot. 2: 71. 1824.]. - Tortula alpina (Bruch \& Schimp.) Bruch., Musci Frond. Exsic.: 163. 1843. - Syntrichia alpina (Bruch. \& Schimp.) Jur., Laubm.-Fl. Oesterr.Ung.: 1939. 1882.

Barbula brachypila Müll. Hal., Nuovo Giorn. Bot. Ital., n.s. 5: 181. 1898.

Barbula erythrotricha Müll. Hal., Nuovo Giorn. Bot. Ital., n.s. 5: 181. 1898. Lectotype (designated by Chen, 1940): China interior, Provincia Shen-si sept., in monte Lao-y-huo prope Schan-gen-ze, 12 Mart. 1897, legit Rev. Jos. Giraldi, determ. Prof. C. Müller sub n. 1800 (H-BR 4205010).

Figs.4, 5: 1, 4-7

Plants small to medium-sized, in dense or loose tufts, dark green above, reddish-brown below. Stem 4-15 mm, erect, irregularly branched, weakly tomentose, with central strand, sclerodermis of 1-2 layers of cells with slightly thickened brownish walls and weakly developed hyalodermis. Leaves densely arranged, appressed and spirally twisted when dry, generally spreading or patent when moist, lingulate-spathulate, not or weakly constricted at midleaf, 2.0-3.5 $\times 0.7-1.5 \mathrm{~mm}$, apex rounded; margins en- tire, plane in distal part and weakly recurved at proximal $1 / 2(-2 / 3)$ or only at mid-leaf; costa strong, reddishbrown, $60-90 \mu \mathrm{m}$ wide at base, weakly tapering distally, smooth on dorsal side, ending in a short or, occasionally, moderately long, 0.1-05(-0.8) mm, weakly denticulate reddish-brown awn, strongly convex dorsally, in transverse section with one layer of guide cells, two layers of smaller adaxial cells, ventral surface papillose, abaxial stereid band of 3-4 cell layers, with hydroids; lamina unistratose, upper and mid-lamina cells roundquadrate or hexagonal, $12.5-20 \times(10-) 12-20 \mu \mathrm{m}$, with 6$8(-12)$ papillae per cell, bifurcate, not pedicellate, 2.5 $\mu \mathrm{m}$ high; basal juxtacostal cells rectangular, 50$115 \times 17.5-35 \mu \mathrm{m}$, thin-walled, sometimes weakly collenchymatose, forming a clearly differentiated hyaline area, basal marginal cells shorter and narrower, chlorophyllose. Autoicous. Inner perichaetial leaves smaller and narrower than stem leaves (ca. $1.5 \times 0.6 \mathrm{~mm}$ ). Antheridia bud-like, perigonial leaves with blunt apices, perigonia situated at some distance below perichaetium. Seta erect, reddish brown, $1-1.5 \mathrm{~cm}$ long, spirally twisted. Capsule reddish brown, 2.5-3.5 mm, cylindrical, straight or slightly curved; operculum long conical, 1.2-1.4 mm long; basal membrane of 3-6 rows of cells, 0.09-0.16(-0.2) $\mathrm{mm}$ high. Spores 12-18 $\mu \mathrm{m}$, finely papillose.

Variability. Syntrichia sinensis possesses a considerable variability of leaf hair-point (see also discussion on p. 16). In all specimens from Europe available for our study length of hair-points do not exceed $0.5 \mathrm{~mm}$ in perichaetial leaves and they are usually shorter, 0.1-0.3 $\mathrm{mm}$, in stem leaves. It is in an agreement with descriptions by European authors, e.g., Gallego, 2005). At the same time, in specimens from China hair-points are often longer, up to $0.8 \mathrm{~mm}$. In Russia, specimens with short hair-points are much more frequent; only few longpointed collections were made in the Russian Far East, Khakassia and Altai (in the latter mostly at places with milder and wetter climate).

Differentiation. Differences from S. submontana are discussed under the latter species. A combination of short awns (to $0.3 \mathrm{~mm}$ in most cases), mostly reddish-brown, and comparatively low basal membrane of peristome (consisting of 3-6 rows of cells) readily separates it from fruiting S. laevipila s. str., which is characterized by longer $(0.5-1.0 \mathrm{~mm})$ and mostly hyaline awns and higher basal membrane (10-20 rows of cells). However, it is more difficult to separate sterile plants of $S$. sinensis from dioicous and always lacking sporophytes $S$. pagorum; most helpful characters are recurved leaf margins to $2 / 3$ the leaf length in $S$. sinensis vs. mostly plane or only weakly recurved at mid-leaf margins of $S$. pagorum, as well as absence of brood leaves in S. sinensis vs. their frequent occurrence in S. pagorum, formed in abundance in axils of upper leaves and on the top of shoot.

Ecology. The species occurs in mesic to rather xeric environments. In Siberia, it largely prefers rocks, espe- 

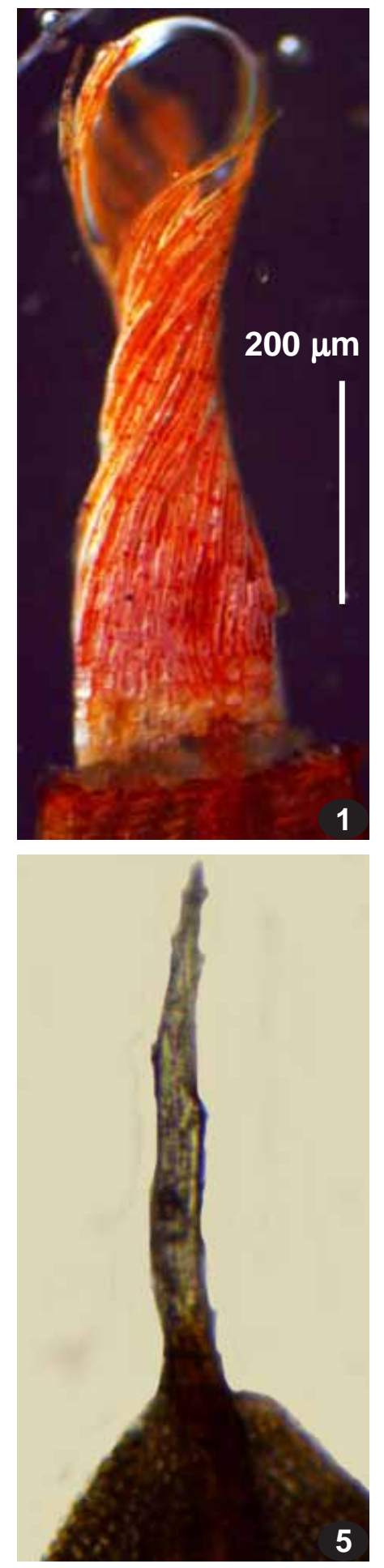

Fig. 5. 1, 4-Syntrichia sinensis (Müll. Hal.) Ochyra (from: Russia, Dagestan, Gunib, Ukrainskaya 14110, LE): 2-3 - S. submontana Broth. (from: Russia, Zabaikalsky Territory, Afonina 5811, LE); 5 Barbula brachypila Müll. Hal. (China interior, Provincia Shen-si sept., prope In-Kia-po, 23 Aug. 1846, legit Rev. Jos. Giraldi, determ. Prof. C. Müller sub n. 1804, LE); 6 - neotype of Barbula sinensis Müll. Hal. (China interior, Provincia Shen-si sept., in monte Lao-y-san, Mart. 1896, legit Rev. Jos. Giraldi, determ. Prof. C. Müller sub n. 1382, H-BR 4205016); 7 - lectotype of Barbula erythrotricha Müll. Hal. (China interior, Provincia Shen-si sept., in monte Lao-y-huo prope Schan-gen-ze, 12 Mart. 1897, legit Rev. Jos. Giraldi, determ. Prof. C. Müller sub n. 1800, H-BR 4205010); 8 - holotype of Tortula submontana Broth. (Turkestan, Or-Tokai - Kutemaldu, 7.VI.1898 leg. \& det. V.F. Brotherus, H 3148373). 1-2 - peristomes; 3-4 perigonia; 5-8 - distal portions of leaf with hair-point. Scale bars: $0.5 \mathrm{~mm}$ for 5-8; $200 \mu \mathrm{m}$ for 1-4. 
cially rock outcrops in open forests, more rarely in open places. It was collected mostly at middle elevations (500$900 \mathrm{~m}$ in Zabaikalsky Territory, to $1400 \mathrm{~m}$ in Buryatia, 400-1000 $\mathrm{m}$ in Altai Mts, and 1100-2200 $\mathrm{m}$ in the Caucasus). In Manhan Mountains in Inner Mongolia, China, however, $S$. sinensis is a common epiphyte and in Altai Mts there are also collections from Salix, Populus, Sorbus, and Betula. Even more common this species is on trees in Dagestan: on Juglans, Pyrus, Prunus, Salix and Carpinus.

Distribution. Syntrichia sinensis has its main distribution in Central and Northern Asia, including China (Li et al., 2001), Japan (Noguchi \& Iwatsuki, 1988), Mongolia (Tsegmed, 2010), Kazakhstan, Turkmenistan, Tajikistan and Kyrgyzstan (Mamatkulov et al., 1998; Ignatov, Afonina, Ignatova et al., 2006), with its northern limit in continental part of the southern Russian Far East and southern Siberia from Transbaikalia to Altai Republic, being not rare in Transbaikalia and Altai. In the Caucasus, S. sinensis was reported from Georgia (Chikovani \& Svanidze, 2004), Armenia (Manakyan, 1995), and Azerbaijan (Lyubarskaya, 1986). In Europe it is known from Germany (Düll \& Meinunger, 1989), Austria (Köckinger et al., 2008), Poland (Ochyra et al., 2003) and Mediterranean countries (Cyprus, Italy, France, NE Spain, Slovenia, Tunisia and Turkey: Gallego, 2005; Pavletić, 1955; Ros et al., 2013). Syntrichia sinensis also occurs in a restricted area in North America, Rocky Mountains in Colorado and New Mexico, where it was only recently discovered (Mishler, 2007).

Selected specimens examined: Specimens collected by J. Giraldi in Schen-si Province, China: sub Barbula sinensis Müll. Hal.: in monte Lao-y-san Mart 1896, det. C. Müller 1382 (H-BR 4205016); in monte Fui-Kio-san, 18 Oct.1896, det. C. Müller 1805 (H-BR 4205015); in monte Kuan-tou-san, 5 Nov. 1896, det. C.Müller 1810 (H-BR 4205019); in monte Tui-Kiosan, 20 Oct.1896, det. Brotherus (H-BR4205017); in monte Tui-Kio-san, 7 Sept. 1896, det. Brotherus (H-BR 4205021); in monte Tui-Kio-san, 19 Oct. 1896, det. Brotherus (H-BR 4205022); in monte Tui-Kio-san, 17 Sept.1896, coll. det. Brotherus (H-BR 4205024); sub Barbula erythrotricha Müll. Hal.: Lao-y-huo prope Schan-gen-ze, 12 Mart 1897, det C. Müller 1800 (H-Br 4205010); in loco dicto Zu-lu, 27.Okt. 1896, det. C. Müller 1803 (H-Br 4205012, FI); in loco non notato, Sept 1896, det. C. Müller 1802 (H-Br 4205011, FI); prope In-Kiapo, 25 Aug 1896, det. Brotherus (H-Br 4205001); in monte Kuan-tou-san, Oct.1897, det. Brotherus (H-Br 4205014); in monte Kan-y-san (calena Sao-y-san), 2 May 1899, det. Brotherus ( $\mathrm{H}-\mathrm{Br} 4205020)$; prope In-Kia-po, 16 Oct. 1897, det. Brotherus (H-Br 4205002, FI); Zu-lu, 13 Oct. 1898, det.Brotherus (H-Br 4205003, FI); Sao-y-san, 1897, det. Brotherus (H-Br 420500); in monte Miao-Wang-san, Jul.1899, det.Brotherus (HBr 4205005); Han-sun-fu, Oct.1899, det. Brotherus (H-Br 4205006); Han-sun-fu, Sept.1898, det. Brotherus (H-Br 4205007, FI); prope In-Kia-po, 27 Mart 1896, det. Brotherus (H-Br 4205008, FI); prope In-Kia-po, 22 Oct 1897, det. Brotherus (H-Br 4205009, FI); sub Barbula brachypila Müll. Hal.: prope In-Kia-po, 23 Aug. 1896, det. C. Müller 1804 (LE).
CHINA: Inner Mongolia: NE of Huhhot, Yingshan Mountains, Manhan Mt., Ignatov 08-510 (MW). MONGOLIA: Khubsugul aimag, Renchinlkhumbe somon, Arasain gol River, U1aankhal Mt., Enkhzhargal 1753 (MHA); Khubsugul aimag, Tsagaan nuur somon, Darkhat depression, Enkhzhargal 1200 (MHA).

ASIATIC RUSSIA: Altai Republic: Teletskoe Lake, 3.VI.1989, Ignatov 87 (LE, MHA); Chulyshman River valley 8-10 km upstream Chulcha River mouth, Ignatov \& Ignatova 12-460 (MW); Chulcha River valley, Ignatov 9/20 (MHA); Ongudai District, Malyj Yaloman, 4.VIII.2000, Ignatova s.n. (MW); Ongudai District, Chuya River, Belyj Bom, Sadaklar Creek, Seregin \& Seregina M-2228 (MHA); Katun River valley $2 \mathrm{~km}$ upstream Bijka Creek, Ignatov \& Ignatova 34/54 (MHA); Shebalino District, Katun River valley $10 \mathrm{~km}$ upstream Chemal, Ignatov \& Ignatova 34/118 (MHA); Shebalino District, Katun River valley near Ust-Sema, Ignatov \& Ignatova 24/52 (MHA). Khakassia: Shirinsk District, Efremenko Settlement, 6.VI.1970, Vasil'ev s.n. (LE). Irkutsk Province: western shore of Baikal Lake, Bol'shie Koty, 11.IX.1981, Filin s.n. (MW). Buryatia: Kyahta District, vicinity of Chikoy Settlement, 2.VI.1985, Bardunov s.n. (IRK, LE); East Sayan Mts, upper of Oka River, Dodo-Zhahna village, 2.VII.2008 (with $S$. longimucronata), Afonina \#0708 (LE). Zabaikal'sky Territory: Akscha District, Bukukun Settlement, 2.III.1910, Mikhno s.n. (LE); Gazimurovsky Zavod, limestone outcrops, 23.VIII.1963, Bardunov s.n. (IRK, LE); Nerchinsky Zavod District, Serebryanka Creek, 1.IX.1963, Bardunov s.n. (IRK, LE); Nerchinsky Zavod, 7.VIII.1989, Bardunov s.n. (IRK, LE); Duldurga District, National park "Alkhanay", 8.VII.2006, Afonina \# 1606 (LE); Nizhny Tsasuchei, rocks along bank of Onon River, 18.VII.2006, Afonina 5306 (LE); Kyra District, 8 km NW of Mangut Settlement, 25.VII.2006, Afonina 7306 (LE); right bank of Ingoda River $5 \mathrm{~km} \mathrm{~S}$ of Darasun railway station (with $S$. longimucronata), 14.VII.2007, Afonina 05107 (LE) Kyra District, Sokhondinsky Reserve (with S. longimucronata), 24.VIII.2011, Afonina 6011 (LE); Sretensk District, Kyrenga River, 19.VII.2012, Afonina 1812 (LE); Gazimuro-Zavodsky District, circa $12 \mathrm{~km}$ SW of Batakan Settlement, 23.VII.2012, Afonina 3512 (LE); Kalar District, right bank of Vitim River near hassing point "Vitim River", 29.VI. 20013, Afonina 0113 (LE). Amurskaya Province: Zeisky Nature Reserve, Tukuringra Mt. Range, $D u$ dov \& Kotel'nikova 2013_Br 0341 (MW). Primorsky Territory: Suchuan River Basin, Ekaterinovka Settlement, 4.IX.1913, Komarov s.n. (LE); Chernigovsk District, Lunza Settlement, 3.X.1934, Lazarenko s.n. (LE); Partizansk District, Lozovyj Range, Chandolaz Mt., Ignatov et al. 06-2778 (MW); Lozo District, Gavrilov Klyuch, Ignatov 07-73 (MW); Chuguevka District, Izvilinka River $5 \mathrm{~km}$ downstream Bereznyaki, Ignatov 07-500 (MHA). CAUCASUS: Adygeya: Malaya Laba, Pastbischnyi Range, 27.VIII.1945, Karpov s.n. (LE); Dagestan: Gunib, 25.V.2009, Ukrainskaya 14286 (LE); same place, surroundings of Mountain botaniacal garden, Ignatov \& Ignatova 09-680, 09-582, 09-213, 09-255 (MW); Gunib District, Keger, Ignatov \& Abakarova 11-153 (MW); Charoda District, Gunukh, Ignatov \& Abakarova 11-4, 11-159 (MW); Charoda District, Urukh-Sota, Ignatov \& Abakarova 11-334 (MHA); Tsudakhar, Sana Creek, Ignatov \& Abakarova 11-385 (MHA). KabardinoBalkaria: Cherek-Balkarsky River valley, Verkhnyaya Balkaria, Ignatov et al. 05-1862 (MW); Cherek-Bezengijsky, 3 km upstream Bezengi, 3.VIII.2004, Ignatov et al. s.n. (MHA). Karachaevo-Cherkessian Republic: Dolina narzanov, 12.VII.2010, Ukrainskaya 14716 (LE); Teberdinsky Nature Reserve, Shumka 
Creek, Ignatov \& Ignatova 05-1041 (MW); Verkhnayaya Teberda, Onipchenko 45/95 (MW); Karachaevsk surroundings, 4.V.2001, Onipchenko s.n. (MW).

\section{ACKNOWLEDGEMENTS}

Authors are greatly indebted to curators if FI, H and PE for specimen loans, to Alexander E. Fedosov for the help with the Bayesian analysis, to Mikhail Kozhin for assistance in mapping Syntrichia submontana, to M.T. Gallego for providing her publications, and to J. Kučera and R.H. Zander for valuable comments and correction of English of the manuscript. The work was partially supported by RFBR № 13-04-01427, 14-04-01424 and RAS program "World Life, Current State and Development".

\section{LITERATURE CITED}

[ABRAMOV, I. I. \& A. L. ABRAMOVA] АБРАМОВ И. И., А. Л. АБРАМОВА 1983. Конспект флоры мхов Монгольской Народной Республики. - [Conspect of moss flora of Mongolian People Republic] Л., Наука [Leningrad, Nauka], 222 pp.

[BROTHERUS, V.F.] БРОТЕРУCВ.Ф. 1931. Мхи Азиатской России (Bryales), ч. III. - [Mosses of Asiatic Russia (Bryales), part III]. Труды Бот. сада АН СССР [Trudy Bot. Sada Akad. Nauk S.S.S.R.] 42: 141-247.

CHEN, P. C. 1941. Studien über die ostasiatischen arten der Pottiaceae. I. - Hedwigia 80: 1-76.

CHIKOVANI, N. \& T. SVANIDZE 2004. Checklist of bryophyte species of Georgia. - Braun-Blanquetia 34: 97-116.

CRUM, H.A. \& L.E. ANDERSON 1981. Mosses of eastern North America. - New York: Columbia University Press. $1328 p p$.

DÜLL, R. \& L. MEINUNGER 1989. Deutschlands Moose. 368 pp.

EDGAR, R.C. 2004. MUSCLE: multiple sequence alignment with high accuracy and high throughput. - Nucleic Acids Research 32: 1792-1797.

GALLEGO, M.T. 2005. A taxonomic study of the genus Syntrichia Brid. (Pottiaceae, Musci) in the Mediterranean region and Macaronesia. $-J$. Hattori Bot. Lab. 98: 47-122.

GALLEGO, M.T., M.J. CANO \& J. GUERRA 2004. A taxonomic study of Syntrichia laevipila (Pottiaceae, Musci) complex. - Bot. J. Linn. Soc. 145: 219-230.

GALLEGO, M.T., O. WERNER, C. SÉRGIO \& J. GUERRA 2005. A morphological and molecular study of the Syntrichia laevipila complex (Pottiaceae) in Portugal. - Nova Hedwigia 80: 301-322.

GARDINER, A., M. IGNATOV, S. HUTTUNEN \& A. TROITSKY 2005 On resurrection of the families Pseudoleskeaceae Schimp. and Pylaisiaceae Schimp. (Musci, Hypnales). - Taxon 54: 651-663.

HALL, T.A. 1999. BioEdit: a user-friendly biological sequence alignment editor and analysis program for Windows 95/98/NT. - Nucleic Acids Symposium Series 41: 95-98.

HUELSENBECK, J.P., F. RONQUIST, B. HALL 2001. MrBayes: bayesian inference of phylogeny. - Bioinformatics 17: 754-755.

IGNATOV, M.S., O.M. AFONINA, E.A. IGNATOVA, A. ABOLINA, T.V. AKATOVA, E.Z. BAISHEVA, L.V. BARDUNOV, E.A. BARYAKINA, O.A. BELKINA, A.G. BEZGODOV, M.A.BOYCHUK, V.YA. CHERDANTSEVA, I.V. CZERNYADJEVA, G.YA. DOROSHINA, A.P. DYACHENKO, V.E. FEDOSOV, I.L. GOLDBERG, E.I. IVANOVA, I. JUKONIENE, L. KANNUKENE, S.G. KAZANOVSKY, Z.KH. KHARZINOV, L.E. KURBATOVA, A.I.MAKSIMOV, U.K. MAMATKULOV, V. A. MANAKYAN, O.M. MASLOVSKY, M.G. NAPREENKO, T. N. OTNYUKOVA, L.YA. PARTYKA, O.YU. PISARENKO, N.N. POPOVA, G.F. RYKOVSKY, D.YA. TUBANOVA, G.V. ZHELEZNOVA \& V.I. ZOLOTOV 2006 [2007]. Check-list of mosses of East Europe and North Asia. - Arctoa 15: 1-130.

IGNATOV, M.S., E.A. IGNATOVA \& S.A. SURAGINA 2002. A new vari- ety of Syntrichia caninervis (Pottiaceae, Musci). - Arctoa 11: 333-336. IGNATOV, M., TS. TSEGMED, B. TAN, X-L. BAI \& V. ZOLOTOV 2004. Mosses of Gobi in Mongolia. - J. Hattori Bot. Lab. 96: 183-210.

KRAMER, W. 1980. Tortula Hedw. Sect. Rurales De Not. (Pottiaceae, Musci) in der östlichen Holarktis. - Bryophyt. Bibl. 21: 1-165.

LI, XING-JIANG 1981. Some new taxa of Pottiaceae from Xizang (Tibet). - Acta Bot. Yunnan 3: 101-112.

LI, XING-JIANG, SI HE \& Z. IWATSUKI 2001. Pottiaceae. - In: Li Xingjiang \& M.R. Crosby (eds.). Moss Flora of China. Vol. 2: 114-249.

[LYUBARSKAYA, L.B.] ЛЮБАРСКАЯ Л.Б. 1986. Конспект флоры листостебельных мхов Азербайджана. - [Conspect of mosses of Azerbaijan] Баку, Инст. Бот. АН АзССР, рукопись деп в ВИНИТИ [Baku, Inst. Bot. Akad. Nauk Azerb. SSR (msc)], 178 pp.

KÖCKINGER, H., M. SUANJAK, A. SCHRIEBL \& C. SCHRÖCK 2008. Die Moose Kärntens. - Sonderreihe Natur Kärnten 4: 1-319.

MAMATKULOV, U.K. 1990. The flora of the bryophytes of the Tadjik SSR. Volume 1. Donish, Duschanbe, $234 \mathrm{pp}$.

[MAMATKULOV, U.K., I.O. BAITULIN \& S.G. NESTEROVA] МАМАТКУЛОВ У.К., И.О. БАЙТУЛИН, С.Г. НЕСТЕРОВА 1998. Мохообразные Средней Азии и Казахстана. - [Bryophytes of the Middle Asia and Kazakhstan] Алматы [Almaty], 232.

[MANAKYAN, V.A.] МАНАКЯН В.А. 1995. Итоги бриологических исследований в Армении. - [Results of bryological studies in Armenia] Arctoa 5: 15-33.

MISHLER, B.D. 2007. Syntrichia.-In: Zander, R.H. (ed.) Flora of Noth America Vol. 27, 618-627.

MÜLLER, C. 1896. Bryologia provinciae Schen-si Sinensis I. - Nuovo Giorn. Bot. Ital., n.s. 3: 89-129.

MÜLLER, C. 1897. Bryologia provinciae Schen-si Sinensis II. - Nuovo Giorn. Bot. Ital., n.s. 4: 245-276.

MÜLLER, C. 1898. Bryologia provinciae Schen-si Sinensis ex collectione Giraldiana III. - Nuovo Giorn. Bot. Ital., n.s. 5: 158-209.

NOGUCHI, A. \& Z. IWATSUKI 1988. Ill. Moss Fl. Japan Pt. 2. - Hattori Bot. Lab., Nichinan, pp. 243-491.

OCHYRA, R., ŻARNOWIEC \& H. BEDNAREK-OCHYRA 2003. Census catalogue of Polish mosses. - Biodivers. Poland 3: 1-372.

PAVLETIĆ, Z. 1955. Prodromus Flore Briofita Jugoslavije, 578 pp.

RAMBAUT, A., A.J. DRUMMOND 2007. Computer program and documentation distributed by the author, website $\underline{h t t p: / / b e a s t}$. bio. ed. ac. uk/Tracer.

ROS, R.M., V. MAZIMPAKA, U. ABOU-SALAMA, M. ALEFFI, T. L. BLOCKEEL, M. BRUGUÉS, R. M. CROS, M. G. DIA, G. M. DIRKSE, I. DRAPER, W. EL-SAADAWI, A. ERDAG, A. GANEVA, R. GABRIEL, J. M. GONZÁLEZ-MANCEBO, C. GRANGER, I. HERRNSTADT, V. HUGONNOT, K. KHALIL, H. KÜRSCHNER, A. LOSADA-LIMA, L. LUÍS, S. D. MIFSUD, M. PRIVITERA, M. PUGLISI, M. S. SABOVLJEVIC, C. SÉRGIO, H. M. SHABBARA, M. SIM-SIM, A. SOTIAUX, R. TACCHI, A. VANDERPOORTEN \& O. WERNER 2013. Mosses of the Mediterranean, an annotated checklist. - Cryptog. Bryol. 34(2): 99-283.

[SAVICZ-LYUBITSKAYA, L.I. \& Z.N. SMIRNOVA] САВИЧ-ЛЮБИЦКАЯ Л.И., З.Н. СМИРНОВА 1970. Определитель листостебельных мхов CССР. Верхоплодные мхи. - [Handbook of mosses of the USSR. The acrocarpous mosses] Л., Наука [Leningrad, Nauka], 822 pp.

STONE, I.G. 1971. The sporophyte of Tortula pagorum (Milde) De Not. - Trans. Brit. Bryol. Soc. 6: 270-277+1 pl. 3 fig.

[TSEGMED, TS.] ЦЭГМЭД Ц. 2001. Монгол орны ховд таних бичиг. - [Moss Flora of Mongolia] Улаанбаaтар [Ulanbator], 473 pp.

[TSEGMED, TS.] ЦЭГМЭД Ц. 2010. Флора мхов Монголии. - [Moss Flora of Mongolia] M. [Moscow], $634 \mathrm{pp}$.

ZANDER, R.H. 1993. Genera of the Pottiaceae: mosses of harsh environments. - Bull. Buffalo Soc. Nat. Sci. 32: 378 pp. 
Appendix 1. Genbank accession numbers and voucher specimen data of Syntrichia specimens other than taken from Genbank.

\begin{tabular}{|c|c|}
\hline S. caninervis & Dagestan \\
\hline S. caninervis & Mongolia \\
\hline S. caninervis & \\
\hline var. astrakhanica & Astrakhan \\
\hline S. caninervis & \\
\hline var. astrakhanica & Mongolia \\
\hline S. caninervis & \\
\hline var. astrakhanica & Taimyr \\
\hline S. caninervis & \\
\hline var. astrakhanica & Ryazan \\
\hline S. laevipila & Krasnodarsky 1 \\
\hline S. laevipila & Krasnodarsky 2 \\
\hline S. laevipila & Krasnodarsky 3 \\
\hline S. montana & Dagestan \\
\hline S. pagorum & Australia \\
\hline S. pagorum & Kabardino-Balkaria \\
\hline S. pagorum & Khakassia \\
\hline S. pagorum & Mongolia \\
\hline S. pagorum & Yakutia \\
\hline S. pagorum & Zabaikalsky 1 \\
\hline S. pagorum & Zabaikalsky 2 \\
\hline S. pagorum & Zabaikalsky 3 \\
\hline S. papillosissima & Dagestan \\
\hline S. princeps & California \\
\hline S. princeps & Kazakhstan \\
\hline S. princeps & Turkmenistan \\
\hline S. ruralis & Altai \\
\hline S. ruralis & Taimyr \\
\hline S. sinensis & Altai 1 \\
\hline S. sinensis & Altai 2 \\
\hline S. sinensis & Amurskaya \\
\hline S. sinensis & Dagestan \\
\hline S. sinensis & Primorsky \\
\hline S. sinensis & Zabaikalsky 1 \\
\hline S. sinensis & Zabaikalsky 2 \\
\hline S. sinensis & Zabaikalsky 3 \\
\hline S. sinensis & China \\
\hline S. submontana & Altai \\
\hline S. submontana & Dagestan \\
\hline S. submontana & Tyva \\
\hline S. submontana & Zabaikalsky \\
\hline S. submontana & Irkutsk \\
\hline S. submontana & China \\
\hline S. submontana & Khakassia \\
\hline S. submontana & Mongolia \\
\hline S. virescens & Kaliningrad \\
\hline S. virescens & Krasnodarsky \\
\hline S. virescens & Orenburg \\
\hline
\end{tabular}

Russia, Dagestan, Ignatov \& Abakarova 11-102 (MHA)

Mongolia, Ignatov 01-663 (MHA)

Russia, Astrakhan Province, 3.V.1997, Suragina s.n. (MHA)

Mongolia, Ignatov \#01-669 (MHA)

Russia, Taimyr, Fedosov 05-547 (MW)

Russia, Ryazan 4.VIII.2009 Volosnova s.n. (MHA)

Russia, Krasnodar Territory, Ignatov \& Ignatova 05-598 (MW)

Russia, Krasnodar Territory, Ignatov \& Ignatova 05-68 (MW)

Russia, Krasnodar Territory, Ignatov \& Ignatova 05-466 (MW)

Russia, Dagestan, Fedosov 10-2-335 (MW)

Australia, 18.XII.1993, Streimann 53305 (MHA)

Russia, Kabardino-Balkaria, Ignatov et al. 05-1540 (MW)

Russia, Khakassia, Abakan, Ignatov \& Spirina 11-5033 (MHA)

Mongolia, Ignatov 01-768 (MHA)

Russia, Yakutia, Lenskie Stolby, 20.VIII.2001, Krivoshapkin s.n.(MW)

Russia, Zabaikalsky Territory, 9.VIII.2011, Afonina s.n. (LE, MHA)

Russia, Zabaikalsky Territory, Afonina 1711 (LE, MHA)

Russia, Zabaikalsky Territory, Afonina 1011 (LE)

Russia, Dagestan, Abakarova 11-168 (MHA)

U.S.A., California, 5.VIII.1989, Ignatov s.n. (MHA)

Kazakhstan., Aksu-Dzabagly, IV.1979, Neshataeva s.n. (MHA)

Turkmenistan, Syunt-Khasardag, 13.IV.1989, Levitskaya s.n. (MHA)

Russia, Altai Republic, Bogoyash, Ignatov 36/266 (MHA)

Russia, Taimyr, Ereechka, Fedosov 13-3-0905 (MW)

Russia, Altai Republic, Teletzkoe Lake, 3.VI.1989, Ignatov s.n. (MHA)

Russia, Altai Republic, Chemal, Ignatov \& Ignatova 34/109. (MHA)

Russia, Amurskaya Province, Dudov \& Kotel'nikova 2013_Br_0341 (MW)

Russia, Dagestan, Abakarova \& Ignatov 11-361 (MHA)

Russia, Primorsky Territory, Chandolaz, Ignatov et al. 06-2825 (MHA)

Russia, Zabaikalsky Territory, Afonina 5306 (LE)

Russia, Zabaikalsky Territory, Afonina 7206 (LE)

Russia, Zabaikalsky Territory, 7.VII.1989, Bardunov s.n. (LE)

China, Inner Mongolia, Manhan Mt., Ignatov 08-510 (MHA)

Russia, Altai, Malyj Yaloman, Ignatov \& Ignatova 25/119 (MHA)

Russia, Dagestan, Abakarova \& Ignatov 11-477 (MHA)

Russia, Tyva, 13.IX.2003, Korobkov s.n. (LE)

Russia, Zabaikalsky Territory, Afonina 1110 (LE)

Russia, Irkutsk Province, Baikal Lake, 14.IX.1982, Filin s.n. (MW)

China, Xizang, Miwa \& Y. Yia 2004080324 (PE)

Russia, Khakassia, Abakan, Ignatov \& Spirina 11-5042 (MHA)

Mongolia, Gurvan-Saikhan, Ignatov 01-658 (MHA)

Russia, Kaliningrad Province, 10.VII.2005, Dolnik s.n. (MHA)

Russia, Krasnodar Territory, Ignatov \& Ignatova 05-206 (MHA)

Russia, Orenburg Province, 3.V.2005, Notov s.n. (MHA)
KM381996

KM381997

KM381998

KM381999

KM382037

KM382036

KM382000

KM382001

KM382002

KM382003

KM382004

KM382005

KM382006

KM382007

KM382008

KM382009

KM382010

KM382011

KM382012

KM382013

KM382014

KM382015

KM382016

KM382017

KM382018

KM382019

KM382020

KM382021

KM382022

KM382023

KM382024

KM382025

KM382026

KM382027

KM382028

KM382029

KM382030

KM382031

KM382032

KM382038

KM382039

KM382033

KM382034

KM382035 